\title{
Child as a Mathematics Teacher: I'm Playing Teaching with my Family
}

\author{
Alper Cihan KONYALIOĞLU \\ Atatürk University, Kazım Karabekir Faculty of Education 25240, “Erzurum”, Turkey, \\ Email: ackonyali@atauni.edu.tr
}

\begin{abstract}
In the study, the children had a mathematics teacher mission of their parents. The purpose of the study is to identify whether this mission provides the children cognitive and affective improvements in their mathematical understanding or not. To this aim, various activities were prepared in line with the program in collaboration with the teacher. These activities were shared with the parents and the children at home.

The sample consists of 3 students from 3 different classes, their parents and their teachers. Observations, semi-structured interviews, interviews with parents and students achievement tests were used as the instruments of the study. The study is a mixed method study with the emphasis on qualitative part. Single case experimental design was used in the quantitative part of the method. Case study design was used in the qualitative part of the study. The data obtained from the achievements tests were evaluated by using measures of central tendency. The remaining data were analyzed through content analysis. In line with the findings, the results show that this method increased the students' achievement in terms of cognitive aspect and made a positive impact on students' affective aspects. Additionally, the method provided self-confidence, created studying with joy and improved the communication among teacher-student-parents.
\end{abstract}

Keywords: Mathematics education, Teaching action, Child, Student as a guide, Parent as a student

\section{Introduction}

The pedagogical, psychological, sociological and neurological basses causing cognitive and affective positivenesses of teaching act exist in the literature. J. Joured said that "teaching is learning twice" and again H. J. Brown "teaching is learning again" based on the Confucius philosophy approximately 5000 years theory.

One of the important learning ways is "to teach" based on the experiences and the accepted theories. Because knowledge should be formed, simplified and organized in order to be taught (Marguez, 2016). This organizes learning. Maybe one of the crucial ways of learning is teaching or trying to teach. There are many studies regarding the importance of teaching for learning in terms of neurological aspect beside the philosophical aspects. Aydın (2016) stated that the brain reacts almost totally to the knowledge coming from outside when learning although it generally reacts locally. The child will use a part of her/his brain when she/he would learn from others. However, most of the parts of the child's brain will be used when the child teaches to others and the capacity of learning will increase remarkably (Aydın, 2016). Again Senemoğlu (2001) stated that left side of the brain is dominant in terms of language, understanding and speaking are intertwined at the right side of the brain. The significance of the teaching act can be revealed when looking at the issue in terms of sense organs besides brain. GüneG (2016) stated that accessing the knowledge is possible with organs such as eyes, ears, tongue, nose and the skin, these affect the level of accessing knowledge and emphasized that the speaking person is also the learning person because the tongue is not for only to taste but also to speak. From this aspect, GüneG (2016) indicated that each teacher is also her/his own student.

As a reason of social constructivism, other social environments are also the effective factors on students' learning as the schools. Peer learning is also a part of social constructivism in the social interaction circle and the peer learning is a considerable amount of positive effects. Being part of the children's learning interaction for parents is unavoidable when they are thought as the most significant actors of informal education environment that they interact with each other continuously. Thus, for parents, spending time with children, listening to them, giving opportunities to express themselves can be the most crucial argument of positive difference in children. This situation enables parents to prepare and conduct activities with their children as the reason of social constructivism indicated by Anderson (1997).

Parent involvement in mathematics education is seen significant based on the literature in terms of; children's cognitive (giĢ̣man, 2002; Yenilmez, Özer and Yıldız, 2006) and affective (Yenilmez et al., 2003) development, helping to decrease the level of mathematics anxiety of children (Alkan, 2011), making positive impacts on children's attitudes towards mathematics and the children's mathematics 
achievements (Alkan, 2011), being a crucial factor on children's internalization of mathematics (Mahdi, 2010), preventing the disconnection between the school and the home (Civil, 1998). To Al-Mahdi (2010) parent's teaching support at home contributes remarkably to the child. The studies revealed these data generally are the studies are the correlational studies focused on the theme of "parents in education". These studies are generally about the relationship between the parents' demographic attributes and the students' achievement. In the literature, any experimental study that the parent has the role of a student of her/his child was not found about the theme "teacher/instructor at home: Children" being helpful for learning of children. That is, any study involving children having the mission of teacher was not found.

In this study, the teacher distributed the activity papers prepared parallel to the daily explained topic at the lesson to the children. Then, the children were required to present these activities as a teacher to their parents. The study was organized with the collaboration of teacher and parents without giving any implication to the children. Parents were informed about the topics and the activities by the teacher in advance. Simply, a parent and teacher communication seminar was organized. In these seminars, parents were provided mathematics simply. They were also tried to have a student mission without giving any implication to their children.

\section{Method}

At the first phase of the study, teachers prepared the activities in collaboration with academicians in line with the literature. Again, the instruments were prepared in a semi structured way to the aim of study. The usefulness of the method, applicability and the impact of the method on the students' achievement were gathered through in class observations and observations at home, semi structured parent interviews, and student achievement tests.

The sample consists of 3 students from 3 different classes, their parents and their teachers on a volunteer basis. The study was thought as a pilot study and it was continued approximately 7 weeks.

Mixed study model enabling the use of both quantitative and qualitative instruments together was used in the study. Mixed method model is a powerful composition enabling gathering data, analyzing data and comparing data by using both quantitative and qualitative techniques in order to find the answer to a research question (Creswell, 2012). Single case experimental design was used in the quantitative part of the method. To Creswell (2012) single case experimental design is the design evaluating the effectiveness of the practice each of the subject in itself by taking repeated measurements from one or more subjects under the standard conditions. In this study, each of the subjects' achievement was measured before the study, during the study and after the study. General class achievement was considered while the study was conducted.

Case study design was used in the qualitative part of the study. Case study is a research design gathering detailed and deeper information from a real life case or current case by using more than one data sources and revealed a case description or case themes (Creswell, 2013). In case studies, several data collection techniques are used as observations, interviews, document analysis, participant observation, focus group interview. Thus, validity and the reliability of the study increase (Creswell, 2013).

Student Achievement Tests: These tests were applied to the students after the topics. The tests are congruent with the curriculum. They were prepared with the professionals. It is aimed with the achievement tests to see the students' achievements difference before and after the practice.

Interviews: Semi structured interviews were applied to the parents in order to receive information about the development towards children's attitudes, interests, wishes and achievements.

Observations: The observations were teachers' in class observations. Difference in students were tried to identify through observations.

It is thought that the observations and interviews conducted during studies reflect the differences on children before, during and after the study, the usefulness, applicability and the effectiveness of the study. The data gathered through all the instruments were analyzed through content analysis, codes, categories and themes were created. The data obtained from the achievements tests were evaluated by using measures of central tendency.

Within the scope of the study it was tried to get benefit from various techniques (Topu, BaydaG, Turan and GöktaG, 2013) for the validity and reliability verification of either the instruction design and development of instruments or all the practice and evaluation phases. To the aim of validity which placed in qualitative studies; describing the process in detail, identifying the assumptions and limitations, the reason for the sample choice and presenting the attributes of it and identifying the roles of researchers were used in the study. To the aim of the reliability, the participation of stakeholders in the process steps 
and receiving expert opinion, data source and diversification of instruments, recording with equipment to prevent data loss in qualitative data and participant confirmatory were used. In each steps of the study, the necessary of the validity and reliability precautions stated above will be used.

\section{Findings}

The findings obtained from the face to face interviews conducted with parents before and after the study as follows.

The questions were asked regarding the children's mathematical achievement, their attitudes towards mathematics and the study environment at home. The parents participated to the study use statements as "medium level" for the mathematics achievement of their children. Also, they stated that they are struggled with helping their children while doing homework; sometimes they are not able to explain the solution of a problem even though they have solved it, they stated that the homework is necessary for children but it is also boring as well as being necessary. Additionally, the parents indicated that they warned their children about doing homework but the children were generally reluctant to do it, even they could not find enough time to play. The parents also indicated that the children believe the necessity of homework but they are worried about the usefulness of the homework.

The findings obtained from the face to face interviews conducted with parents regarding the usefulness of the method, the applicability of the method, and cognitive and affective differences on children as follows.

Parents indicated that the method is useful. They stated that engaging with this type of activity instead of the other standard type of homework eased their and their children's burden, they stated that the method was not boring for the them and their children, it was like a play and this method provided them to spend more time with their children.

A. Is this kind of method activity done out of class? Why?

E1. "I have already with her while doing homework every evening for a long time. This was boring and tiring both for me and my child. I felt relaxed through the application of this method. My child does not also get bored. We play together."

E2."I am carrying out both the homework and the play together. My child both play with me and repeats the topic. My child wants to begin the activity willingly without waiting my start. To me, responsibility can be gained in this way well"

E3. "My child is happier than before. It is not boring as homework... That's it's good... In this way, I spent more time with my child. My child's homework was even boring to me".

First of all, parents stated that the method can be applicable in terms of budget, research and the engagement.

A. Is this kind of method activity done out of class? Why?

E1. “Applicable. It doesn't have any cost. What should be...a board, pencil...the child explain what she learned at school. I bought a board to use at home."

E2. “We applied already. It's easy...For my child. It's easy to do. It's for my child. She explains in front of the board, and I'm listening"

E3. "We have already help with the homework, and it was boring...but it's enjoyable and easy for the child. Sometimes she is hooked on the activity. We ask for permission with our by raising our hands. She also emulates her teacher. The method is remarkably useful."

A. What's your gain with this method? Do you think that you have gained something? Which kind of advantages and disadvantages does the method have?

E1. "My child began to be more confident. She began to like the reputation of the lesson more than before. It's like a play for her... Maybe I don't spend more time compared to before but to me it's productive..."

E2. "My child express herself better than before. She speaks everything. She does this without our compel. It's more productive... 
E3. "She's more self-confident than before. Happier...so, we are also happy too...She doesn't get bored. She plays.

Parents first of all, stated that this method increased their children's mathematics achievement, their interest, attitudes towards mathematics. The parents stated that their children took responsibilities with enjoyment.

A. Is there any difference on your child's achievement? How?

E1. Yes...she seems to solve questions easily in these topics... E2. To me, yes...more successful... eager...teacher also said.

E3. She says shall we do mathematics all the time. She says the questions are easy...She does...her achievement is better.

A. Is there any difference on your child's attitudes towards mathematics? How?

E1. Yes. There is a difference. She wants to solve her sister's questions. But, I don't allow her to solve them because the older one is at high school... My child is more eager and interested ...she likes playing teaching...she likes...

E2. She was struggled with mathematics before...she didn't like mathematics so much but she did a one-eighty... we also frighten the children...

E3. Her self-confidence increased...She enjoys...eager...more relaxed...

Findings related to the in class observations of teachers are follow:

Observations of teacher shows that children began to be more sociable and active, they began to be more confident and eager to participate to the lesson.

A. Which kind of difference that you observed during the study?

Ö1. The child is more relax and self-confident...more sociable...more interesting compared to the beginning....she says "I can do"...

Ö2. She is more active and excited... she has enthusiasm for learning...probably for the idea to teach elders... Ö3. She sometimes wants to solve in front of the board by explaining...to me it's good...she's not shy...

A. What are the advantages of this study to you?

Ö1. In this way, we meet with parents frequently and try to solve a problem if there exists...The incrase on achievement makes us happy.

Ö2. There are more connections with parents than before. To me this is positive...the child is better...

Ö3. It's good for both for the child and us...the child makes it obvious that the parents are also more caring...

In the study process, achievement tests were applied periodically to the class in which the student attends. Improvement of the student was tried to revealed quantitatively compared with the other students were not included in the study. In advance, an achievement test applied by the teacher for each student was also took attention.

Data obtained from the achievement tests revealed that all the three students' achievement increased. These students show an increasing trend in their mathematical achievement. 3 achievement tests were applied to the students in 7 weeks. The tests used before the study was used as the Pretest (PT). Students' scores for each achievement tests (AT) and class averages were presented in Table 1 below. 
Table1: Students' Achievement Test Scores and Grade Point Averages

\begin{tabular}{llll}
\hline & & Scores & Class averages \\
\hline \multirow{4}{*}{ PT } & Student 1 & 60,00 & 73,61 \\
& Student 2 & 75,00 & 74,50 \\
& Student 3 & 75,00 & 73,00 \\
& Student 1 & 85,00 & 75,28 \\
AT1 & Student 2 & 90,00 & 81,09 \\
& Student 3 & 95,00 & 76,04 \\
& Student 1 & 100,00 & 78,88 \\
AT2 & Student 2 & 90,00 & 80,86 \\
& Student 3 & 95,00 & 80,20 \\
& Student 1 & 95,00 & 79,27 \\
AT3 & Student 2 & 100,00 & 81,30 \\
& Student 3 & 100,00 & 79,80 \\
\cline { 2 - 3 } & & &
\end{tabular}

As can be seen in Table 1. The students participated to the study performed close to the class average at the beginning of the study. However, they achieved to perform above the average during the application of the study.

\section{Conclusion}

Generally the research findings revealed that this method can be applicable and useful in line with the teachers' and parents' ideas. Again, different from the peer learning, this method based on child's teaching to his/her parent provided positive improvements on students' mathematical achievements and their attitudes towards mathematics.

The findings referring to the increase on students' achievement on the cognitive dimension is congruent with the studies of giG̣man (2002), Al-Mahdi (2010) and Yenilmez et al. (2003) focusing on the parent-child interaction, and with the studies of Alkan (2011) and Yenilmez et al.(2003) focusing on the affective aspect of the parent-child interaction.

The findings of the studies show that standard homework causes to get bored, having responsibility with compelling, doing homework without willingness. As it is known in some countries such as Finland students are not required to do homework. The findings of this study show that this type of method would be more helpful and useful rather than the standard homework. The findings revealed that this method is applied willingly, is far from being boring, enjoyable and interactive. That is, the research findings shows that this method revealed anxiety, increases interest, and done with willingness. The positive effect of this method reveals anxiety when it is considered that the mathematics anxiety is one of the obstacles in learning mathematics Alkan (2011).

Again, this type of application can bring into force the parent-student-teacher interaction and communication and school-parents collaboration which do not process effectively (Halat and Kay, 2009). With this applied method, a more interactive and professional education environment which is a part of the aim-increasing mathematical achievement of students can be created suggested Halat and Kay (2009) by increasing the interaction of parent-student-teacher-principal.

\section{References}

Alkan, V. (2011). Etkili matematik öğretiminin gerçekleĢtirilmesindeki engellerden biri: Kaygı ve nedenleri.

Pamukkale Üniversitesi Eğitim Fakültesi Dergisi, 29(1), 89-107.

Al-Mahdi, O. (2010). A qualitative investigation of home-school relationships and children's mathematics learning in-and out-of-school in Bahrain. Procedia-Social and Behavioral Sciences, 8, 427-438.

Anderson, A. (1997). Families and mathematics: A study of parent-child interactions. Journal for Research in Mathematics Education. 28(4). 484-511. 
Aydın,0.(2016). Çocuğunuzun Beynini GeliG̣tirecek 10 Yöntem. http://www.cocukgelisimi.gen.tr. UlaG̣ım tarihi: 15.05.2016.

Creswell, J.W.(2012). Educational Research: Planning, Conducting, and Evaluating Quantitative and Qualitative Research. (4.Ed.) Boston: Pearson Education.

Creswell, J.W. (2013). Research design: Qualitative, quantitative, and mixed methods approaches. Sage Publications, USA.

Civil, M. (1998). Bridging in-school mathematics and out-of-school mathematics. Paper presented at the annual meeting of the American Educational Research Association, San Diego, CA. Retrieved July 12, 2014 from http://math.arizona.edu/

GüneG̣, A.(2016). Eğitimde Kalıcı BaĢarı Ġçin Edinerek Öğrenme. Ġstanbul. IG̣ık Yayınları.

Halat, E. and Kay, O. (2009). Yeni 2005 ilköğretim matematik öğretim programının veli görüG̣leri doğrultusunda değerlendirilmesi: Eğitim düzeyi. The assessment of the new elementary school mathematıcs teaching program through parents. Erzincan Üniversitesi Eğitim Fakültesi Dergisi, 11(2).

Marguez, G.G.(2016). Anlatmak Ǵçin YaĢamak. (Çeviren. P. SavaG̣). 12. Baskı. Ġstanbul: Can Yayınları (2002). Senemoğlu,N.(2001). GeliĢim, Öğrenme ve Öğretim.Ankara. Gazi Kitapevi Yayınları.

giG̣man, M.(2002). Eğitimde Mükemmellik ArayıG̦ı. Ankara. Pegem A Yayınları.

Topu, F. B., BaydaG̦, Ö., Turan, Z., and GöktaG̦, Y. (2013). Öğretim teknolojisi araĢtırmalarında geçerlik ve güvenirlik önlemleri. Çukurova Üniversitesi Eğitim Fakültesi Dergisi, 42(1), 110-126

Yenilmez, K., Özer, M. N. and Yıldız, Z. (2006). Velilerin çocuklarının matematik eğitimine karĢı yaklaG̣ım ve katkılarının incelenmesi üzerine bir araG̣tırma. EskiG̣ehir Osmangazi Üniversitesi Sosyal Bilimler Dergisi, 7 (1), 151-170. 